\title{
PERTANGGUNGJAWABAN NOTARIS TERHADAP PERJANJIAN DIBAWAH TANGAN YANG TELAH DILEGALISASI YANG MENGANDUNG PERBUATAN MELAWAN HUKUM
}

\author{
Dina Nurkharisma, Budi Santoso, Irma Cahyaningtyas \\ Program Studi Magister Kenotariatan \\ Fakultas Hukum, Universitas Diponegoro \\ Email: dina.nurkharisma@gmail.com
}

\begin{abstract}
The notary has the authority to legalize the deed under the hand requested by the parties. But often in the deed under the hand contains elements of acts against the law. This study aims to describe the responsibilities of a notary to his profession as a general official making an authentic deed, and to describe the notary's responsibility for an underhand agreement that contains elements of illegal acts that have been legalized. The method used in this article is normative juridical, which is a secondary data analysis with statute approach and conceptual approach that has descriptive analytical reasearch spesifications. The results of research in this article, namely: first, the notary's responsibility towards his profession as an official of an authentic deed is only limited to the formal form of an authentic deed, not to the contents of the deed, every act carried out by a notary can be held accountable if there is a violation committed and the act can cause harm for the parties. Second, the notary liability for an underhand agreement that contains elements of illegal acts that have been legalized, that is, the notary is not responsible for the contents of the deed under the hand even though there is a clause in the act against the law.
\end{abstract}

\section{Keywords: liability; notary; legalization}

\begin{abstract}
Abstrak
Notaris memiliki wewenang untuk melakukan legalisasi akta dibawah tangan yang dimohonkan oleh para pihak. Namun seringkali dalam akta dibawah tangan mengandung unsur perbuatan melawan hukum. Penelitian ini bertujuan untuk mendeskripsikan tanggungjawab notaris terhadap profesinya sebagai pejabat umum pembuat akta autentik, dan untuk mendeskripsikan pertanggungjawaban notaris terhadap perjanjian dibawah tangan yang mengandung unsur perbuatan melawan hukum yang telah dilegalisasi. Metode yang digunakan dalam artikel ini adalah yuridis normatif, yaitu telaah data sekunder dengan pendekatan undang-undang dan pendekatan konseptual yang memiliki spesifikasi penelitian deskriptif analitis. Hasil penelitian dalam artikel ini, yaitu: pertama tanggungjawab notaris terhdap profesinya sebagai pejabat pembuat akta autentik hanya terbatas bentuk formal akta autentik bukan terhadap isi akta, setiap perbuatan yang dilakukan oleh notaris bisa dimintakan pertanggungjawaban apabila ada suatu pelanggaran yang dilakukan dan perbuatan itu dapat menimbulkan kerugian bagi para pihak. Kedua, pertanggungjawaban notaris terhadap perjanjian dibawah tangan yang mengandung unsur perbuatan melawan hukum yang telah dilegalisasi yaitu notaris tidak bertanggungjawab terhadap isi akta dibawah tangan meskipun di dalamnya ada klausula perbuatan melawan hukum.
\end{abstract}

Kata kunci: pertanggungjawaban; notaries; legalisasi 


\section{A. Pendahuluan}

Jasa dari notaris sangat dibutuhkan dalah kehidupan masyarakat, salah satunya yaitu untuk menyatakan kehendak dengan alat bukti yang autentik. Berdasarkan Pasal 1 angka 1 Undang-Undang No 2 Tahun 2014 tentang Perubahan Atas Undang-Undang Nomor 30 Tahun 2004 tentang Jabatan Notaris (selanjutnya disebut UUJN), Notaris adalah pejabat umum yang berwenang untuk membuat akta autentik dan memiliki kewenangan lainnya sebagaimana dimaksud dalam Undang-Undang ini atau berdasatkan Undang-Undang lainnya. Akta autentik dapat dijadikan alat bukti dalam persidangan perdata maupun pidana. Menurut Pasal 1870 Kitab Undang-undang Hukum Perdata akta notaris adalah akta autentik merupakan alat bukti tertulis yang mempunyai kekuatan pembuktian sempurna. Sedangkan menurut Pasal 184 Undang-Undang No. 8 Tahun 1981 tentang Kitab Undang-Undang Hukum Acara Pidana, alat bukti yang sah adalah: (Kitab Undang-Undang Hukum Acara Pidana, 1981) a. Keterangan saksi; b. Keterangan ahli; c. Surat; d. Petunjuk; e. Keterangan terdakwa. Akta autentik yang dibuat oleh notaris tersebut masuk dalam alat bukti petunjuk.

Pengertian Akta itu sendiri berdasarkan Pasal 165 Staatsblad Tahun 1941 Nomor 44 (HIR), akta adalah surat yang diperbuat demikian oleh atau dihadapan pegawai yang berwenang untuk membuatnya menjadi bukti yang cukup bagi kedua belah pihak dan ahli warisnya maupun berkaitan dengan pihak lainnya sebagai hubungan hukum, tentang segala hal yang disebut di dalam surat itu sebagai pemberitahuan hubungan langsung dengan perihal pada akta itu (Herziene Inlandsch Reglement, n.d.). Sementara itu, berdasarkan Pasal 1868 Kitab Undang-Undang Hukum Perdata, suatu akta autentik ialah suatu akta yang dibuat dalam bentuk yang ditentukan oleh undang-undang, dibuat oleh atau dihadapan pegawai-pegawai umum yang berkuasa itu untuk ditempatkan dimana akta dibuatnya (Kitab Undang-Undang Hukum Perdata, n.d.). Menurut Herlin Budiono, Pasal 1868 Kitab Undang-undang Hukum Perdata tidak menjelaskan mengenai siapa yang dimaksud dengan pegawai/ pejabat umum dan bagaimana bentuk akta autentik, tetapi Undang-Undang Nomor 30 Tahun 2004 tentang Jabatan Notaris menunjuk notaris sebagai pejabat umum serta memberi dasar dan tata cara pembuatan akta autentik (Budiono, 2013).

Macam-macam akta notaris di dalam Pasal 1 angka 7 UUJN, akta notaris adalah akta autentik yang dibuat oleh atau di hadapan notaris menurut bentuk dan tata cara yang ditetapkan dalam Undang-Undang. Dengan demikian terdapat dua macam akta notaris yaitu akta yang dibuat oleh notaris (akta relaas) yang merupakan akta yang dibuat oleh notaris memuat uraian secara autentik dari notaris mengenai suatu tindakan yang dilakukan atau secara suatu keadaan yang dilihat atau disaksikan di dalam menjalankan jabatannya sebagai notaris, dan akta yang 
dibuat di hadapan notaris/ akta pihak (akta partij) yaitu akta yang dibuat di hadapan notaris memuat uraian dari apa yang diterangkan atau diceritakan oleh para pihak yang menghadap kepada notaris.

Selain akta autentik terdapat akta lain yang ada yaitu akta dibawah tangan yang ditegaskan di dalam Pasal 1874 Kitab Undang-undang Hukum Perdata yang menyebutkan sebagai tulisan-tulisan dibawah tangan dianggap akta-akta yang ditanda tangani dibawah tangan, surat-surat, register-register, surat-surat urusan rumah tangga, dan lain-lain tulisan yang dibuat tanpa perantara seorang pegawai umum.

Hal tersebut menunjukkan bahwa akta dibawah tangan pada dasarnya merupakan akta yang dibuat oleh para pihak dengan membuat perjanjian tanpa melibatkan pegawai umum yang salah satunya yaitu notaris. Menurut Yahya Harahap daya kekuatan pembuktian akta dibawah tangan tidak memiliki kekuatan pembuktian luar sebagaimana akta autentik yang tidak bisa dibantah kebenarannya oleh hakim, dengan demikian harus pihak lawan yang mengajukan pembuktian kepalsuan atas akta tersebut, disini pembuktian akta dibawah tangan ini memiliki kekuatan hukum yang sangat lemah (Harahap, 2005).

Menurut Soepomo sebagaimana dikemukakan Yahya Harahap jika ditinjau dari segi pembuktiannya, agar suatu tulisan memiliki nilai sebagai akta dibawah tangan diperlukan beberapa persyaratan pokok, diantaranya: pertama, surat atau tulisan tersebut ditanda tangani, kedua isi yang diterangkan didalamnya menyangkut mengenai perbuatan hukum (Rechtshandeling) atau hubungan hukum (Rechtsbetrekking) dan yang ketiga sengaja dibuat untuk dijadikan bukti dari perbuatan hukum yang dibuat di dalamnya (Harahap, 2005). Kekuatan pembuktiannya hanya antara para pihak tersebut apabila para pihak tersebut tidak menyangkal dan mengakui adanya perjanjian tersebut (mengakui tanda tangannya di dalam perjanjian yang dibuat). Oleh sebab itu, salah satu pihak dapat menyangkal akan kebenaran tanda tangan yang ada dalam perjanjian tersebut.

Hal di atas dapat disimpulkan bahwa apabila terjadi permasalahan hukum, maka akta dibawah tangan ini memiliki pembuktian yang sangat lemah. Senada dengan R. Subekti yang menyatakan bahwa pembuktian adalah meyakinkan hakim mengenai kebenaran dalil atau dalildalil yang dikemukakan dalam suatu persengketaan (Subekti, 2001). Oleh karenanya untuk memperkuat akta dibawah tangan dapat dilakukan suatu legalisasi terhadap akta dibawah tangan yang dilakukan oleh pejabat yang berwenang yaitu notaris. Menurut Pasal 56 UUJN, surat di bawah tangan yang disahkan atau dilegalisasi wajib diberi teraan cap/stempel serta paraf dan tanda tangan notaris (Undang-Undang Nomor 30 Tahun 2004 Tentang Jabatan Notaris, 2004). Kewenangan notaris untuk mengesahkan tanda tangan dan menetapkan 
kepastian tanggal surat di bawah tangan dengan mendaftarkan di dalam buku khusus (legalisasi) yang sebagaimana diatur di dalam Pasal 15 ayat (2) huruf a UUJN. Para pihak dalam hal ini hanya tanda tangan di hadapan notaris dimana notaris tidak memastikan isi mengenai suatu akta apakah isinya suatu perbuatan melawan hukum atau tidak, meskipun di dalamnya para pihak tanda tangan di hadapan notaris, namun akta yang dibuat merupakan akta di bawah tangan, bukan akta notaris.

Namun, terdapat permasalahan lain, yaitu bagaimanakah pertanggungjawaban notaris mengenai akta dibawah tangan yang sudah dilegalisasi yang di dalamnya memuat perbuatan melawan hukum. Sebagai pejabat umum khususnya di bidang hukum perdata, notaris diharapkan menduduki posisi yang netral, dengan demikian dapat diharapkan dapat memberikan informasi atas tindakan hukum yang dilakukan notaris atas permintaan kliennya yang berdasarkan Undang-Undang, dan notaris diharapkan tidak boleh memihak kepada kliennya agar mencegah terjadi suatu masalah (Prastomo \& Khisni, 2017).

Berdasarkan uraian diatas akan dirumuskan dua permasalahan, yaitu: Pertama, apa saja yang menjadi tanggung jawab notaris terhadap profesinya sebagai pejabat umum pembuat akta autentik; Kedua, bagaimanakah pertanggungjawaban notaris terhadap perjanjian di bawah tangan yang mengandung unsur perbuatan melawan hukum yang telah dilegalisasi olehnya.

Berdasarkan penelusuran yang telah dilakukan, ditemukan beberapa artikel yang membahas terkait tentang Pertanggungjawaban Notaris Terhadap Perjanjian Dibawah Tangan Yang Telah Dilegalisasi Yang Mengandung Perbuatan Melawan Hukum yaitu: Pertama, artikel yan membahas mengenai penerapan legalisasi oleh Notaris atas akta di bawah tangan memberikan kepastian bagi hakim mengenai tanggal, identitas, maupun tandatangan dari para pihak yang bersangkutan dan terkait dalam perjanjian tersebut serta tanggungjawab Notaris atas kebenaran akta dibawah tangan yang dilegalisainya terkait kepastian tanda tangan artinya pasti bahwa yang tanda tangan itu memang pihak dalam perjanjian, bukan orang lain (Dinaryanti, 2013). Kedua, artikel yang membahas mengenai Akta Notaris yang dibuat tanpa tanda tangan para pihak mempunyai kekuatan mengikat jika ada pengganti dari tanda tangan tersebut, yaitu sidik jari atau cap jempol dan harus ditegaskan dalam akta keterangan Notaris dalam hal ini Notaris bertanggung jawab atas akta di tandatangani maupun akta yang menggunakan sidik jari (Sajadi, 2015). Ketiga, artikel yang membahas mengenai pertanggungjawaban notaris atas kebenaran akta di bawah tangan yang dilegalisasinya adalah kepastian tanda tangan artinya pasti bahwa yang tanda tangan itu memang pihak dalam perjanjian, bukan orang lain (Puspa, 2016). 
Artikel yang ditulis ini memiliki perbedaan dengan beberapa artikel yang telah disebutkan sebelumnya. Artikel ini lebih fokus membahas mengenai Tanggung Jawab Notaris Terhadap Profesinya Sebagai Pejabat Umum Pembuat Akta Autentik dan Pertanggungjawaban Notaris Terhadap Perjanjian Dibawah Tangan Yang Mengandung Unsur Perbuatan Melawan Hukum Yang Sudah Dilegalisasi.

\section{B. Metode Penelitian}

Metode penelitian yang digunakan dalam artikel ini adalah yuridis normatif yaitu telaah data sekunder seperti peraturan, putusan, perjanjian, atau dokumen hukum lainnya, serta hasil penelitian (Syah, 2020). Dalam artikel ini akan dijelaskan dengan menggunakan pendekatan undang-undang (statute approach) dan pendekatan konseptual (conceptual approach). Spesifikasi penelitian dalam artikel ini adalah deskriptif-analitis, yaitu proses pemecahan masalah yang diselidiki dengan menggambarkan atau melukiskan keadaan subjek atau objek penelitian (Ode, 2012). Penelitian hukum yang bersifat normatif selalu menitikberatkan pada sumber data sekunder. Data sekunder pada penelitian dapat dibedakan menjadi bahan hukum primer, bahan hukum sekunder dan bahan hukum tersier (Diantha, 2013). Berdasarkan ruang lingkup, tujuan dan pendekatan dalam penelitian ini, teknik pengumpulan data yang digunakan adalah studi kepustakaan dari data sekunder. Analisis data dilakukan secara normatif-kualitatif. Kajian normatif berupa analisis pertanggungjawaban notaris terhadap perjanjian dibawah tangan yang telah dilegalisasi yang mengandung perbuatan melawan hukum.

\section{Pembahasan}

\section{Tanggung Jawab Notaris Terhadap Profesinya Sebagai Pejabat Umum Pembuat Akta}

\section{Autentik}

Menurut Pasal 1 angka 1 UUJN, Notaris merupakan pejabat umum yang berwenang untuk membuat akta autentik dan memiliki kewenangan lainnya sebagaimana dimaksud dalam Undang-Undang ini atau berdasarkan Undang-Undang lainnya. Jabatan notaris lahir karena masyarakat membutuhkannya bukan jabatan yang diciptakan kemudian baru di sosialisakikan kepada masyarakat luas. Sebagai pejabat umum yang diberikan kepercayaan untuk mengemban sebagian tugas negara, notaris tidak bisa menghalalkan segala cara untuk mencapai profesionalnya (Saputro, 2008).

Notaris merupakan pejabat umum sebagaimana duraikan didalam Pasal 1 angka 1 UUJN, dengan demikian sebagai pejabat umum notaris merupakan satu-satunya pejabat yang memiiki wewenang untuk memuat akta autentik tentang perbuatan, perjanjian, dan 
penetapan yang diharuskan oleh suatu peraturan umum atau oleh yang berkepentingan dikehendaki untuk dinyatakan dalam suatu akta autentik, semuanya sepanjang pembuatan akta tersebut oleh peraturan umum tidak jua ditegaskan atau dikeculikan kepada pejabat lain atau orang lain. Pejabat lain sebagaimana dimaksud didalam Pasal 1 angka 1 UndangUndang No 2 Tahun 2014 adalah:(Untung, 2002)

a. Consul (Berdasarkan Conculair Wet)

b. Bupati Kepala Daerah atau Sekretaris Daerah yang ditetapkan oleh Mentri Kehakiman

c. Notaris pengganti

d. Jurus Sita pada Pengadilan Negeri

e. Pegawai Catatan Sipil

Menurut Soegondo Notodisoerjo untuk membuat akta autentik, seseorang mesti memiliki kedudukan sebagai pejabat umum, di Indonesia seorang pengacara meski ia ahli di bidang hukum, tidak memiliki wewenang untuk membuat akta autentik, karena pengacara tidak memiliki kedudukan sebagai pejabat umum. Sebaliknya seorang Pegawai Catatan Sipil (Ambtenaar Van de Burgerlijke) meski ia tidak ahli hukum ia berhak membuat akta-akta autentik yang digunakan untuk hal-hal tertentu, contohnya untuk membuat akta kelahiran, akta kematian, akta perkawinan, hal yang demikian karena pegawai catatan sipil ditetapkan sebagai pejabat umum dan diberikan wewenang untuk membuat akta-akta tersebut (Soedjendro, 2001).

Wewenang Notaris diatur di dalam Pasal 15 ayat 1, 2, dan 3 UUJN, yang menyebutkan yaitu sebagai berikut:

Notaris berwenang membuat akta autentik mengenai semua perbuatan, perjanjian dan penetapan yang diharuskan oleh peraturan perundang-undangan, dan/atau yang dikehedaki oleh yang berkepentingan untuk dinyatakan dalam akta autentik, menjamin kepastian tanggal pembuatan akta, menyimpan akta memberikan grosse, salinan dari kutipan akta, semuanya itu sepanjang pembuatan akta itu tidak juga ditugaskan atau dikecualikan kepada pejabat lain atau orang lain yang ditetapkan oleh undang-undang.

(1) Selain kewenangan sebagaimana dimaksud pada ayat 1 notaris berwenang pula:

a. Mengesahkan tanda tangan dan menetapkan kepastian tanggal surat di bawah tangan dengan mendaftar dalam buku khusus

b. Membukukan surat di bawah tangan dengan mendaftar dalam buku khusus

c. Membuat kopi dari asli surat di bawah tangan berupa salinan yang memuat uraian sebagaimana ditulis dan digambarkan dalam surat yang bersangkutan

d. Melakukan pengesahan kecocokan fotokopi dengan surat aslinya 
e. Memberikan penyuluhan hukum sehubungan dengan pembuatan akta

f. Membuat akta yang berkaitan dengan pertanahan, atau

g. Membuat akta risalah lelang

(2) Setiap kewenangan sebagimana dimaksud pada ayat (1) dan ayat (2), notaris mempunyai kewenangan lain yang diatur dalam peraturan perundang-undangan.

Tanggung jawab yang dimiki oleh notaris menganut prinsip tanggung jawab berdasarkan kesalahan (Based of fault of liability). Dalam pembuatan akta autentik, notaris harus bertanggung jawab apabila atas akta yang dibuat terdapat kesalahan atau pelanggaran terjadi dari pihak penghadap, maka sepanjang notaris melaksanakan kewenangannya sesuai peraturan, notaris yang bersangkutan tidak dapat dimintai pertanggungjawaban, karena dalam hal ini notaris hanya mencatat apa yang disampaikan oleh para pihak untuk dituangkan ke dalam akta, keterangan palsu yang disampaikan oleh para pihak merupakan menjadi tanggung jawab para pihak (Afifah, 2017). Hal ini juga sesuai dengan teori tanggung jawab hukum yang dikemukakan oleh Hans Kelsen yang menyebutkan bahwa seseorang bertanggung jawab secara hukum atas perbuatan tertentu atau bahwa dia memikul tanggung jawab hukum (Kelsen, 2007). Dengan demikian, segala perbuatan hukum yang dilakukan oleh notaris dalam hal ini pembuatan akta otentik, maka sudah tentu ia bertanggung jawab apabila terdapat kesalahan sepanjang perbuatan notaris sesuai dengan peraturan perundang-undangan. Apabila ia terbukti bersalah maka sudah wajar apabila ia mendapatkan sanksi sebagai konsekwensi tanggung jawab tersebut.

Namun, pada dasarnya dalam hal ini notaris tidak memiliki tanggung jawab terhadap isi akta yang dibuat dihadapannya, dikarenakan mengenai isi dari akta itu adalah kehendak dan merupakan kesepakatan yang diinginkan oleh para pihak. Notaris hanya menuangkan kesepakatan tersebut ke dalam bentuk akta autentik dengan demikian notaris hanya bertanggungjawab terhadap bentuk formal akta autentik yang sebagaimana yang ditetapkan di dalam Undang-Undang. Notaris hanya memiliki peran untuk melakukan pencatatan atau menuangkan suatu perbuatan hukum yang dilakukan oleh para pihak yang menghadap ke dalam akta. Notaris hanya bertanggung jawab untuk mengkonstatir apa yang terjadi apa yang dialaminya, dan apa yang dilihat oleh para pihak yang menghadap dan menyesuaikan syarat-syarat formil pembuatan akta autentik kemudian dituangkan ke dalam akta notaris. Di dalam hal ini notaris tidak diwajibkan untuk menyelidiki kebenaran mengenai isi materiil dari akta autentik itu dengan demikian secara tidak langsung hal ini mewajibkan notaris untuk bersikap netral dan tidak memihak dan memberikan nasihat hukum bagi klien yang meminta petunjuk hukum pada notaris yang bersangkutan. 
Jadi dengan demikian dapat disimpulkan yaitu kecuali isi akta setiap perbuatan yang dilakukan oleh notaris bisa dimintakan pertanggungjawaban apabila ada suatu pelanggaran yang dilakukan dan perbuatan itu dapat menimbulkan kerugian bagi para pihak. Notaris harus mempertanggungjawabkan kebenaran materiil akta apabila nasihat hukum yang diberikan ternyata dikemudian hari merupakan suatu hal yang salah atau keliru. Notaris yang melakukan kesalahan baik disengaja atau tidak yang melakukan perbuatan pelanggar hukum dan menyebabkan orang lain mengalami kerugian maka notaris dapat dikenai sanksi sebagaimana yang diatur di dalam Pasal 84 UUJN yang menyatakan yaitu dapat menjadi alasan bagi pihak yang menderita kerugian untuk menuntut penggantian biaya, ganti rugi dan bunga kepada notaris. Ganti rugi yang dimaksud diatur didalam Pasal 1365 Kitab Undang-undang Hukum Perdata yang menyebutkan, tiap perbuatan melanggar hukum yang membawa kerugian kepada orang lain, mewajibkan orang yang karena salahnya menerbitkan kerugian ini, menggantikan kerugian tersebut. Dengan demikian dari bunyi Pasal tersebut untuk dapat dikenakan ganti rugi kepada notaris harus terpenuhi perbuatan yang melanggar hukum, harus ada suatu kesalahan, harus ada kerugian yang ditimbulkan, dan adanya hubungan perbuatan dan kerugian.

\section{Pertanggungjawaban Notaris Terhadap Perjanjian Dibawah Tangan Yang}

\section{Mengandung Unsur Perbuatan Melawan Hukum Yang Sudah Dilegalisasi.}

Pertanggungjawaban dalam Kamus Besar Bahasa Indonesia memiliki arti perbuatan (hal dan sebagainya) bertanggung jawab; sesuatu yang dipertanggungjawabkan. Pertanggungjawaban ini juga melekat pada profesi Notaris sebagai pejabat umum, baik pertanggungjawaban hukum perdata dan pidana. Sofian mengutip Hart dan Honore menyatakan terdapat tiga elemen penting terkait pertanggungjawaban dalam hukum, yaitu definisi pertanggungjawaban menurut hukum, dasar hukum atribusi pertanggungjawaban, serta kasus-kasus hukum yang menjadi dasar perbedaan pertanggungjawaban (Sofian, 2018).

Pertanggungjawaban Notaris telah diatur dalam Pasal 65 UUJN, yang menyatakan bahwa: "Notaris, Notaris Pengganti, Notaris Pengganti Khusus, dan Pejabat Sementara Notaris bertanggung jawab atas setiap akta yang dibuatnya meskipun Protokol Notaris telah diserahkan atau dipindahkan kepada pihak penyimpan Protokol Notaris." Menurut Abdul Ghofur sebagaimana dikutip oleh Herianto Sinaga, membedakan empat poin terkait notaris sebagai pejabat umum memiliki tanggungjawab terhadap kebenaran materiil akta yang dibuatnya, yaitu: 
1. Tanggung jawab notaris secara perdata terhadap kebenaran materiil terhadap akta yang dibuatnya;

2. Tanggung jawab notaris secara pidana terhadap kebenaran materiil dalam akta yang dibuatnya;

3. Tanggung jawab notaris berdasarkan peraturan jabatan notaris (UUJN) terhadap kebenaran materiil dalam akta yang dibuatnya;

4. Tanggung jawab notaris dalam menjalankan tugas jabatannya berdasarkan kode etik notaris. (Sinaga, 2015)

Salah satu pertanggungjawaban notaris adalah terhadap perjanjian dibawah tangan yang mengandung unsur perbuatan melawan hukum yang sudah dilegalisasi. Berdasarkan Kitab Undang-undang Hukum Perdata Pasal 1313, memuat pengertian perjanjian, yaitu merupakan suatu perbuatan dengan mana satu orang atau lebih mengikatkan dirinya terhadap satu orang lain atau lebih maka terjalinlah suatu perikatan yang lahir karena perjanjian (HS, 2017).

Perbuatan melawan hukum merupakan perbuatan yang menimbulkan kerugian, dan secara normatif perbuatan tersebut tunduk pada ketentuan Pasal 1365 Kitab Undang-undang Hukum Perdata. Disini Pasal 1365 Kitab Undang-undang Hukum Perdata menganut tanggung jawab yang berbentuk tanggung gugat berdasarkan kesalahan (liability based fault). Hal ini dilihat dalam ketentuan Pasal tersebut yang mensyaratkan adanya kesalahan pada pelaku untuk sampai kepada keputusan apakah pebuatan seseorang itu merupakan perbuatan melawan hukum. Selain itu unsur kesalahan harus dibuktikan oleh pihak yang menderita kerugian sebagaimana yang diatur dalam Pasal 1865 Kitab Undang-undang Hukum Perdata dan 163 HIR (Sjaifurrachman, 2011).

Salah satu perjanjian yang mengandung perbuatan melawan hukum yaitu perjanjian antara Raden Dwi Laksono sebagai pihak pertama dan Haji Mohammad Himawan Salim Harjo sebagai pihak kedua yang berisi sebagai berikut:

- Bahwa pihak pertama adalah seseorang persero dari perseroan komanditer CV Kondang Murah yang berkedudukan di Surakarta, yang didirikan dengan akta tertanggal 15 Oktober 1998 nomor 12, dibuat di hadapan Eunike Ratna Widjaja, Sarjana Hukum, Notaris di Surakarta yang sudah didaftarkan di kepaniteraan PN Surakarta tertanggal; 23 Oktober 1998 di bawah Nomor 83/CV, Juncto akta tertanggal 19 Maret 2005 nomor 35 dibuat dihadapan Herry Prabowo Kurniawan, Sarjana Hukum, Notaris di Klaten yang telah didaftarkan di Kepaniteraan Pengadilan Negeri Surakarta tertanggal 18 April 2005 di bawah nomor 80 CV.05, Juncto akta tertanggal 18 April 2016 nomor 150, dibuat di hadapan Ina Megahwati, Sarjana Hukum, Notaris di Surakarta, yang telah didaftarkan di Kepaniteraan Pengadilan Negeri Surakarta tertanggal 26 April 2016 di bawah nomor 115/HK/CV/IV/2016 Nomor 37, dibuat di hadapan Ina Megawati, Sarjana Hukum, Notaris Surakarta.

- Bahwa uang yang telah digunakan oleh pihak pertama untuk menyetor modal ke dalam perseroan komanditer tersebut adalah berasal dari dan telah dibayar oleh pihak kedua. 
Berhubung dengan apa yang diuraikan di atas maka para pihak setuju untuk membuat perjanjian dengan syarat-syarat dan ketentuan-ketentuan yaitu sebagai berikut:

- Pihak pertama dengan ini mengaku, bahwa uang yang telah dipergunakan oleh pihak pertama untuk menyetor modal ke dalam perseroan komanditer tersebut yang jumlahnya dapat dilihat dari pada buku-buku perseroan adalah berasal dari dan telah dibayar pihak kedua.

- Karena uang yang disetor adalah milik pihak kedua maka pihak pertama mengaku bahwa modal yang disetor ke dalam perseroan komanditer adalah milik pihak kedua.

- Pihak pertama dengan ini berjanji dan mengikatkan diri terhadap pihak kedua, bahwa sewaktu-waktu pihak kedua berhak untuk meminta dan menerima modal yang disetor tersebut dari pihak pertama untuk ditulis dan dibalik nama (dipindahkan) kepada pihak kedua atau kepada pihak lain yang ditunjuk oleh pihak kedua.

- Dalam hal pihak pertama meninggal dunia, ditaruh di bawah pengampuan atau dinyatakan jatuh pailit maka penyerahan modal yang disetor tersebut harus dianggap telah dilakukan oleh pihak kedua satu hari sebelum pihak pertama meninggal dunia, ditaruh di bawah pengampuan atau dinyatakan jatuh pailit, sehingga modal yang disetor kedalam perseoran komanditer tersebut hanya sebagai titipan dari pihak kedua.

- Dalam hal terjadinya penyerahan modal tersebutpihak pertama tidak berhak menuntut suatu ganti rugi berupa apapun kepada pihak kedua.

- Pihak pertama dengan ini menerangkan selama modal yang disetor tersebut belum diserahkan dan dibalik nama (dipindahkan) kepada pihak kedua atau kepada pihak lain yang ditunjuk oleh pihak kedua, maka pihak pertama akan menjauhkan diri dari segala perbuatan yang dapat menimbulkan kerugian bagi pihak kedua.

- Pajak-pajak dan beban-beban lain mengenai modal yang disetor tersebut selama masih tertulis atas nama pihak pertama ditanggung dan dibayaroleh pihak kedua, demikian juuga semua keuntungannya adalah menjadi hak dan milik pihak kedua sendiri.

- Pihak pertama dengan ini dan juga dengan akta tersendiri memberi kuasa kepada pihak kedua untuk menghibahkan, memindahkan hak, mengoperkan dan menyerahkan modal tersebut kepada siapapun juga termasuk pihak kedua sendiri, menghadiri rapat-rapat perseroan, menerima uang pembayaran keuntungan sekaligus mengundurkan diri dari perseroan komanditer CV. Kondang Murah.

- Kuasa yang tersebut dalam akta ini maupun yang dibuat dengan akta tersendiri tersebut tidak dapat dicabut kembali atau berakhir kerena merupakan bagian yang tidak dapat dipisahkan dari perjanjian yang dimaksud dalam akta ini dan jika tanpa kuasa-kuasa mana niscaya perjanjian ini tidak dilangsungkan dan demikian kuasa-kuasa tersebut diberikan dengan melepaskan segala ketentuan dalam undang-undang yang mengatur tentang sebab-sebab berakhirnya suatu kuasa.

- Tentang akta ini dan segala akibatnya, para pihak menerangkan telah memilih tempat kediaman yang sah dan tetap di kantor kepaniteraan Pengadilan Negeri di Surakarta.

Perjanjian tersebut melibatkan 3 notaris yang berdomisili di Surakarta. Meskipun telah melibatkan 3 notaris di Surakarta, kenyataannya perjanjian yang dibuat mengandung unsur perbuatan melawan hukum. Unsur yang mengandung perbuatan melawan hukum tersebut yaitu:

"pihak pertama dengan ini berjanji dan mengikatkan diri terhadap pihak kedua, bahwa sewaktu-waktu pihak kedua berhak untuk meminta dan menerima modal yang disetor tersebut dari pihak pertama untuk ditulis dan dibalik nama (dipindahkan) kepada pihak kedua atau kepada pihak lain yang ditunjuk oleh pihak kedua. Apabila pihak pertama 
meninggal dunia, ditaruh di bawah pengampuan atau dinyatakan jatuh pailit maka penyerahan modal yang disetor tersebut harus dianggap telah dilakukan oleh pihak kedua satu hari sebelum pihak pertama meninggal dunia, ditaruh di bawah pengampuan atau dinyatakan jatuh pailit, sehingga modal yang disetor kedalam perseoran komanditer tersebut hanya sebagai titipan dari pihak kedua."

Dapat dilihat bahwa perjanjian yang dibuat oleh Raden Dwi Laksono sebagai pihak pertama dan Haji Mohammad Himawan Salim Harjo sebagai pihak kedua menimbulkan kerugian bagi pihak pertama. Hal ini disebabkan karena pihak kedua dapat mengambil uang yang disetor oleh pihak pertama sewaktu-waktu dan bahkan ketika pailit pihak pertama tetap berkewajiban untuk mengembalikan uang milik pihak kedua. Sehingga dapat disimpulkan perjanjian tersebut merupakan perjanjian yang mengandung unsur perbuatan melawan hukum sebagaimana diatur dalam Pasal 1365 Kitab Undang-Undang Hukum Acara Perdata yang berbunyi: "apabila setiap perbuatan melawan hukum yang oleh karenanya menimbulkan kerugian pada orang lain, mewajibkan orang yang karena kesalahannya menyebabkan kerugian untuk mengganti kerugiannya."

Sesuai dengan ketentuan dalam Pasal 1365 KUHPerdata, maka suatu perbuatan melawan hukum haruslah mengandung unsur-unsur sebagai berikut:

1. adanya sutau perbuatan (perbuatan dalam hal ini adalah melakukan kesepakatan dengan membuat perjanjian);

2. perbuatan tersebut melawan hukum (secara sadar melakukan perjanjian yang menimbulkan kerugian bagi pihak pertama);

3. adanya kesalahan dari pihak pelaku (pihak kedua dengan sengaja telah melakukan kesalahan dengan melakukan perjanjian yang menimbulkan kerugian bagi pihak pertama);

4. adanya kerugian bagi korban (pihak kedua dapat mengambil uang yang disetor oleh pihak pertama sewaktu-waktu dan bahkan ketika pailit pihak pertama tetap berkewajiban untuk mengembalikan uang milik pihak kedua);

5. adanya hubungan kausal antara perbuatan-perbuatan dengan kerugian (Prastomo \& Khisni, 2017).

Terkait legalisasi oleh notaris, dapat dikaitkan dengan tata cara legalisasi yang memenuhi syarat sesuai dengan Pasal 1874 a Kitab Undang-undang Hukum Perdata yang berisi: "Jika pihak yang berkepentingan menghendaki, di luar hal termaksud dalam alinea kedua pasal yang lalu, pada tulisan-tulisan di bawah tangan yang ditandatangani, dapat juga diberi suatu pernyataan dari seorang Notaris atau seorang pejabat lain yang ditunjuk undangundang, yang menyatakan bahwa si penanda tangan tersebut dikenalnya atau telah diperkenalkan kepadanya, bahwa isi akta telah dijelaskan kepada si penanda tangan, dan bahwa setelah itu penandatanganan dilakukan di hadapan pejabat tersebut. Dalam hal ini berlaku ketentuan alinea ketiga dan keempat dan pasal yang lalu.” 
Hal tersebut memperlihatkan bahwa sesuai dengan Pasal 1874 a Kitab Undang-undang Hukum Perdata dan uraian pada bab sebelumnya, pada dasarnya dalam hal ini notaris tidak memiliki tanggung jawab terhadap isi akta yang dibuat dihadapannya, dikarenakan mengenai isi dari akta itu adalah kehendak dan merupakan kesepakatan yang diinginkan oleh para pihak. Apakah sebuah akta merupakan perbuatan melawan hukum atau tidak, notaris tidak bertanggung jawab mengenai hal tersebut. Tanggung jawab notaris hanya sebatas memberikan kepastian hukum mengenai tanggal, identitas, maupun tanda tangan dari para pihak atas perjanjian tersebut, artinya adanya suatu kepastian atas akibat hukum dibawah tangan yang menyatakan bahwa tanda tangan itu memang benar semua pihak hadir dan mengetahui isi dalam perjanjian tersebut karena sudah dibacakan notaris, bukan ada pihak lain dikarenakan semua yang dilakukan didepan notaris. Dengan demikian tidak dimungkinkan adanya pengingkaran di kemudian hari.

\section{SIMPULAN}

Berdasarkan hasil penelitian dan analisis pada artikel ini, maka dapat disimpulkan, Pertama, yang menjadi tanggung jawab notaris terhadap profesinya sebagai pejabat umum pembuat akta autentik meliputi segala perbuatan hukum yang dilakukan oleh notaris dalam hal ini pembuatan akta otentik sepanjang perbuatan notaris sesuai dengan peraturan perundang-undangan, dengan demikian Notaris hanya bertanggungjawab terhadap bentuk formal akta autentik yang sebagaimana yang ditetapkan di dalam Undang-Undang. Notaris disini hanya menuangkan kesepakatan tersebut ke dalam bentuk akta autentik. Kedua, pertanggungjawaban notaris terhadap perjanjian di bawah tangan yang mengandung unsur perbuatan melawan hukum yang telah dilegalsasi adalah tidak memiliki tanggung jawab terhadap isi akta yang dibuat dihadapannya. Hal ini dikarenakan isi dari akta adalah kehendak dan merupakan kesepakatan yang diinginkan oleh para pihak. Apakah sebuah akta merupakan perbuatan melawan hukum atau tidak, notaris tidak bertanggung jawab mengenai hal tersebut. Tanggung jawab notaris hanya sebatas memberikan kepastian hukum mengenai tanggal, identitas, maupun tanda tangan dari para pihak atas perjanjian tersebut, karena dalam proses legalisasi notaris sudah membacakan isi perjanjian yang sudah disepakati oleh para pihak.

\section{DAFTAR PUSTAKA}

\section{A. Buku :}

Budiono, H. (2013). Dasar Teknik Pembuatan Akta Notaris. Bandung: PT Citra Aditya Bakti.

Diantha, I. M. P. (2013). Metodologi Penelitian Hukum Normatif dalam Justifikasi Teori Hukum. 
Jakarta: Kencana.

Harahap, M. Y. (2005). Pembahasan Permasalahan dan Penerapan KUHAP. Jakarta: Sinar Grafika.

HS, S. (2017). Teknik Pembuatan Akta Perjanjian (TPA Dua). Jakarta: Rajawali Pers.

Kelsen, H. (2007). Teori Umum Hukum Dan Negara Dasar-Dasar Ilmu Hukum Normatif Sebagai Ilmu Hukum Deskriptif-Empirik. Jakarta: BEE Media Indonesia.

Ode, M. D. La. (2012). Etnis Cina Indonesia Dalam Politik. Jakarta: Yayasan Obor.

Saputro, A. D. (2008). Jati Diri Notaris Indonesia, Dulu, Sekarang, Dan Di Masa Datang. Jakarta: PT Gramedia Pustaka Utama.

Sjaifurrachman. (2011). Aspek Pertanggungjawaban Notaris Dalam Pembuatan Akta. Bandung: Mandar Maju.

Soedjendro, J. K. (2001). Perjanjian Peralihan Hak Atas Tanah Yang Berpotensi Konflik. Yogyakarta: Kanisisu.

Sofian, A. (2018). Ajaran Kausalitas Hukum Pidana. Jakarta: Kencana.

Subekti, R. (2001). Hukum Pembuktian. Jakarta: Pradya Pramita.

Syah, A. S. R. (2020). Perundang-undangan Indonesia Kajian Mengenai Ilmu Dan Teori Perundang-Undangan Serta Pembentukannya. Makasar: CV.Sosial Politic Genius.

Untung, B. (2002). Visi Global Notaris. Yogyakarta: Andi Publisher.

\section{B. Artikel Jurnal:}

Afifah, K. (2017). Tanggung Jawab Dan Perlindungan Hukum Bagi Notaris Secara Perdata Terhadap Akta Yang Dibuatnya. Lex Renaissance, 2, 147-161.

Dinaryanti, A. R. (2013). Tinjauan Yuridis Legalisasi Akta Di Bawah Tangan Oleh Notaris. Jurnal Ilmu Hukum Legal Opinion, 1.

Prastomo, D. A., \& Khisni, A. (2017). Akibat Hukum Akta Di Bawah Tangan Yang Dilegalisasi Oleh Notaris. Jurnal Akta, 4, 727-738.

Puspa, whenayu T. (2016). Tanggung Jawab Notaris Terhadap Kebenaran Akta Di bawah Tangan Yang Dilegalisasi Oleh Notaris. Jurnal Repertorium, 2, 154-163.

Sajadi, I. (2015). Tanggung Jawab NotarisTerhadap Keabsahan Akta Notaris Yang Dibuatnya Atas Penghadap Yang Tidak Dapat Membaca Dan Menulis. Jurnal Repertorium, 2, $177-$ 186.

Sinaga, H. (2015). Tanggung jawab Werda Notaris Terhadap Akta Yang Dibuatnya. Premise Law Jurnal, 6, 1-12. 


\section{Undang-undang dan Peraturan:}

Undang-Undang Nomor 30 Tahun 2004 Tentang Jabatan Notaris. , (2004).

Undang-Undang Republik Indonesia Nomor 2 Tahun 2014 Tentang Perubahan Atas UndangUndang Nomor 30 Tahun 2004 Tentang Jabatan Notaris. , (2014).

Kitab Undang-Undang Hukum Acara Pidana. , (1981).

Kitab Undang-Undang Hukum Perdata.

Herziene Inlandsch Reglement. 